\title{
Imunovir defended
}

SIR - In a letter published on 31 January $^{1}$, Dimitri Viza makes a number of assertions about Imunovir (inosine pranobex) and the "aggressive publicity campaign" which he suggests has been mounted to promote it. M. Visa's intention seems to be to criticize not just the product but also the journals and newspapers (specifically Nature, the Sunday Times and the Financial Times) which published articles on Imunovir (which is spelt with one $\mathrm{m}$ ). In doing so he has made some errors, which I would like to correct.

First, M. Viza states that “ . . . this drug is already better known from its promotion than its results". More than 300 papers have appeared on Imunovir, including many in journals such as Lancet, International Journal of Immunopharmacology and Antimicrobial Agents and Chemotherapy. As an example of this "promotion", M. Viza states ". . . US drugstore bookstalls hyped the drug with a paperback which claimed a cure for herpes

Although the author did not support this claims with any scientific publications, the book claimed him to be 'an authority on herpes'". The book in question, Herpes: Cause and Control ${ }^{2}$, is an independent text on herpes by Dr William $\mathrm{H}$. Wickett, former director of Student Health Services at California State University, Fullerton. The book discusses a wide range of preparations used to treat herpes, including acyclovir, idoxuridine and Imunovir. However, the latter is at all times referred to as "the test drug": not once is any generic or brand name used, and Dr Wickett states that this is at the request of the manufacturers. It is difficult to see how a book can "hype" a drug without once referring to it by name. Moreover, the book does not claim a cure for herpes. I quote Dr Wickett: "We found that those patients taking the test drug were cured of their Herpes bout in nearly $60 \%$ of the cases at the end of one week. Those taking the placebo were cured, by the same criteria, in about $14 \%$ of cases." Assuming that $M$. Viza is a doctor, he should know that herpes simplex is a recurrent disease and that curing a "bout" is not at all the same thing as curing the disease itself.

Neither the US discoverers of Imunovir, Newport Pharmaceuticals, nor Edwin Burgess Limited which distributes the product in the United Kingdom, has ever claimed that it can cure herpes. To quote the Financial Times article ${ }^{3}$, also criticized by $M$. Viza, "[The company] is quick to point out, however, that the product is not a cure for viruses like herpes, only a moderator of the disease".

This brings me to another assertion, that if Imunovir is effective in herpes, the number of patients in France, Germany, Italy and Spain, where the drug has been available for some years, would have decreased. Imunovir certainly appears to reduce the severity ${ }^{4-8}$ and frequency 9,10 of recurrent attacks of herpes simplex, but as it is not held up to be a cure, the number of patients with herpes can hardly be expected to decrease. In addition, the number of cases is probably related more to increasingly relaxed sexual attitudes than to available therapy.

To move on to the criticism of the article in the Sunday Times ${ }^{11}$, it seems to be the headline that has caused offence: "Pill for AIDS - but it may come too late". Headlines are written not by authors of articles, but by sub-editors. In fact the Sunday Times article referred to work in "preAIDS" patients in New York, the results of which were presented to an audience of genitourinary specialists in London and are at present awaiting publication. The work was sufficiently encouraging for similar trials to be set up both in London and the United States to see whether the findings can be confirmed. These are now under way. The statement in the Financial Times" - "Imunovir may be able to prevent AIDS" - also refers to the New York study. M. Viza takes objection to another statement from that newspaper which suggests that Imunovir shows promising potential in a variety of diseases. I would like to draw his attention to the words of the jury which awarded Imunovir the "Prix Galien" in 1982, an award established in France to recognize major thera- peutic innovation. (Other products honoured by the award include rifampicin in 1970 and cimetidine in 1979.) The distinguished professional jury stated that Imunovir "has transformed the basis of immune therapy and opens new hopes in the field of medicine as important and diverse as viral diseases, autoimmune disease, allergy, parasitology and cancer".

M. Viza is right when he says that responsible lay publications should not give rise to false hopes about potential "breakthroughs", and I believe that we would all be glad to see an end to sensational headlines which bear little relationship to the article, and to the "wonder drug" type of story in general. I dispute the idea that the articles to which $M$. Viza refers, including the one in Nature ${ }^{12}$, are anything but wellbalanced, responsible pieces of reporting based on the scientific evidence available.

Edwin Burgess Ltd, HELEN J. WRIGHT Longwick Road, Princes Risborough, Aylesbury, Bucks HPI7 9RP, UK

1. Viza, D. Nature 313, 344 (1985)

2. Wickett, W.H. Ji Herpes: Cause and Control (Pinnacle, New York, 1982).

3. Rapoport, C. Financial Times, 10 October, p.7 (1984).

4. Corey, L. et al. Clin. Res. 27, 41A (1979).

5. Wickett, W.H. et al. 76th Annual Meeting Am. Soc. Microbiol., New Jersey 1976.

6. Bradshaw, L.J. et al. 4th Int. Cong. Immun., Paris 1980 (Abstr.).

Lassus, A. et al. Ist Sexually Transmitted Diseases World Congress, Puerto Rico, November 1981.

8. Bunta, S. 13th Interscience Conference Antimicrob. Ag. Chemother., Washington, September 1973.

Chang, W-T. et at. 13th Interscience Conference Antimicrob. Ag. Chemother., Washington, September 1973.

10. Galli, M. Lancet il, 331, 1982.

11. Deer, B. Sunday Times 14 October, p.9 (1984).

12. Wenz, C. Nature 311, 404 (1984).

\section{Status of IVF embryos}

SIR - An unfertilized egg is both human and alive, being a detached bit of its mother's body; but it cannot develop further without something positive being done to it from outside, namely fertilization. Otherwise it must inevitably die and, since nobody would claim that it therefore has a right to be fertilized, some would argue that if the "right to life" depends upon being human and alive, fertilization should make no real difference in this respect. But there is of course a fundamental difference, because when the egg fuses with the sperm a new living human organism comes into being, biologically as distinct from both of its parents as it will ever be, and none the less so for the possibility that it may still be able to give rise to twins. This newly created organism has within itself the potential to complete its development as a human person, which it will normally do unless it dies of its own accord, or is killed by a procured abortion. Whether or not at such an early stage it is to be regarded as a "human being", or only potentially one, it is hard to see what difference this should make to its rights to be allowed to realize its full potential without being deliberately destroyed.

There is however an important difference between the potential for futher devel- opment possessed by an egg fertilized normally inside its mother, and an embryo produced artificially by in vitro fertilization (IVF) outside her body. This is that whereas the embryo in utero has of itself the full potential to complete its development without any further intervention from outside, that is not so with IVF, when it requires another positive act in putting it back into a woman's uterus.

So far as completing its development is concerned, therefore, the IVF embryo can be compared with an unfertilized egg, since neither can do this without some positive intervention from outside. It is this, rather than the small size and lack of any visible signs of humanity, that may justify the use of IVF embryos for experimental work expected to result in death, which would anyway be unavoidable whether or not the experiments had been performed. The ethical problems that arise when embryos in utero are to be intentionally aborted are certainly quite different from those involved with experimentation in vitro, since even from the earliest stages they would otherwise have had a chance of completing their normal development.

C.B. GoOdhaRT

University Department of Zoology,

Downing Street,

Cambridge CB2 $3 E J$, UK 